\title{
America's Marine Highway stakeholders: a system-scale analysis of influence in decision making
}

\author{
Amit J. Mokashi ${ }^{1}$ (D) A Austin Becker ${ }^{2}$. James J. Corbett ${ }^{3}$ \\ Received: 23 April 2020 / Accepted: 9 July 2020 / Published online: 24 July 2020 \\ (C) The Author(s) 2020, corrected publication 2020
}

\begin{abstract}
This work surveys stakeholders of America's Marine Highway to identify their perceived influence on each other's resource allocation decision making. The value/criticality of the resource held by the stakeholder group can be indirectly measured by the influence exerted by the group on its peers and its external stakeholders. The stakeholder map visualizes how the various stakeholder groups influence each other. Survey of the US Marine Highway stakeholders reveals peers as the most dominant influence among shippers, environmental advocates, and regulators. Results suggest that only suppliers and transportation providers exhibit distinct dominance of customer-supplier influence over that of their peers. This snapshot of stakeholder relationships is a powerful tool for both businesses as well as regulators in their pursuit of shared objectives in a network-centric environment. Stakeholder relationship influence results, and their graphical illustration, contribute to understanding the underlying dynamics of a changing value advantage in the current and coming decades of shipping.
\end{abstract}

Keywords Stakeholder · Influence · Peers · America’s Marine Highway

Electronic supplementary material The online version of this article (https://doi.org/10.1007/s13437-02000212-0) contains supplementary material, which is available to authorized users.

Amit J. Mokashi

amokashi@njcu.edu

1 School of Business, New Jersey City University, Jersey City, NJ, USA

2 Department of Marine Affairs, University of Rhode Island, Kingston, NY, USA

3 College of Earth, Ocean, and Environment, University of Delaware, Newark, NY, USA 


\section{Introduction}

"Even more than other parts of the nation's transportation system, marine transportation is a joint private- and public-sector enterprise. The private sector owns and operates the vessels and most of the terminals -it is responsible for the commerce that flows through the system. The public sector provides much of the infrastructure at ports and on the waterways - it is responsible for keeping the system functioning in support of commerce, and for doing so in a safe, secure, and environmentally sound manner" (National Research Council (U.S.). Committee for a Study of the Federal Role in the Marine Transportation System 2004).

Stakeholders of America's Marine Highway (AMH) have individual priorities that need to be considered and balanced whenever any actor makes a decision that impacts the system as a whole. Since the maritime transportation system provides a public good to local and national society, the priorities of the public's stake in the AMH should be considered. When it comes to such societal benefits, public policy decision-makers need to understand the best places to intervene in the system to maximize efficiency. A stakeholder-based approach to planning, managing, and regulating systems depends on understanding how the various stakeholders influence the system as a whole. This research presents a methodology for identifying the perceived influence of five stakeholder groups with respect to trading these resources within the marketplace.

\subsection{America's Marine Highway}

Waterways were historically the mode of choice due to their efficiency in labor as well as effort. As Adam Smith famously noted: "A broad-wheeled waggon, attended by two men, and drawn by eight horses, in about six weeks' time carries and brings back between London and Edinburgh near four-ton weight of goods. In about the same time a ship navigated by six or eight men, and sailing between the ports of London and Leith, frequently carries and brings back two-hundred-ton weight of goods. Six or eight men, therefore, by the help of water-carriage, can carry and bring back in the same time the same quantity of goods between London and Edinburgh, as fifty broadwheeled waggons, attended by a hundred men, and drawn by four hundred horses." (Smith 2007, p. 19)

The example illustrated by Adam Smith precisely conveys the advantages that marine transportation has over the traditional land modes, even in the domestic movement of freight. This form of coastal marine transportation is also called short sea shipping or marine highways in the USA. It is a subset of the shipping industry, defined by various characteristics, such as political (national/regional boundary), geographical (region, coastline, water depth, inland/river, contiguous/connected land, i.e., connected by bridges or tunnels), vessel types (size, design, cargo), or cargo operations (feeder, regional intermodal traffic) (Musso et al. 2010). This study focuses on stakeholders of AMH. AMH, in its current form, emerged from the "Energy Independence and Security Act of 2007" SEC. 1121. § 55605, which defines US Short Sea Transportation as "... the carriage by vessel of cargo that is contained in intermodal cargo containers and loaded by crane on the vessel; or loaded on the vessel by means of wheeled technology and that is loaded at a port in the United States and unloaded either at another port in the United States or at a port in Canada located in the Great Lakes 
Saint Lawrence Seaway System or vice-versa." US “short sea shipping” operators continue to enjoy a captive market under the Jones Act cabotage law, which puts significant restrictions on international vessels trading between US states (Merchant Marine Act of 1920 1920). However, the market for movement of goods within the contiguous USA is contestable, and the potential for competition exists from other modes.

\subsection{Stakeholder theory}

Stakeholder theory has had its share of proponents as well as critics. One prominent such critic was the Nobel Laureate Milton Friedman, who insisted that the stakeholder approach was "pure and unadulterated socialism" (Friedman 2007). It is a criticism bourne from the wide range of entities that end up being considered as qualifying under the numerous wide definitions of the term "stakeholder." It is, therefore, necessary to be able to differentiate between stakeholder groups. This work uses a relatively restrictive definition of stakeholder proposed by Max Clarkson (Clarkson 1994, p. 5; Friedman and Miles 2006, p. 6): “[stakeholders] Bear some form of risk as a result of having invested some sort of capital, human or financial, something of value in a firm ... [or] ... are placed at risk as a result of a firm's activities." Thus, the stakeholder, here, is an entity involved with the AMH system or placed at risk as a result of its activities.

\subsection{Stakeholder network}

Individual stakeholders in the AMH network relate to each other due, in part, to their resource interdependence (Roome 2001). Single actors (individuals or organizations) rarely exist or act without external support. As Rowley (1997) proposes in his seminal paper, stakeholder relations are not dyadic (connection between exactly two entities) but rather a network of relations. Rowley points out that since all stakeholders do not directly influence each other, the primary (intermediary) has the power to control the indirect influence of the secondary stakeholder and that this explains (or predicts) the way the stakeholders in it would behave. This shift towards a multistakeholder network, with fragmented influence, makes policymaking a complex exercise both in conception and execution (Klijn 2008).

A stakeholder network permits the stakeholders to influence outcomes using indirect influence where a direct influence on a stakeholder is relatively weaker than an indirect path of influence. In a policy context, this network of stakeholders can be characterized as "a set of political actors who engage in resource exchange over public policy (policy decisions) as a consequence of their resource interdependence" (Compston 2009, p. 11). This exchange can be explained by the principle of reciprocity, i.e., "the giving of benefits to another in return of benefits received" (Molm 2010). Others see this as a "resource dependence network," in which the bases of power dependence are resource inequalities (Knoke and Chen 2008). The term "resource" in these definitions means anything that is controlled by one actor/ stakeholder, which is desired by another and can be traded in some relevant sense (Compston 2009). As Freeman (2010, p. 27) points out, "No stakeholder stands alone in the process of value creation. The stakes of each stakeholder group are multifaceted and inherently connected to each other." 
This approach towards policy development, therefore, matches seamlessly with the stakeholder theory (stakeholders being actors in policy arenas). When we measure the influence, we can gauge the criticality of the resource, which the influencer possesses, to the influenced. The primary tradable resources in the policy context include policy amendments, access, veto power, information, cooperation with implementation, recourse to courts, political support, patronage, private investment, and fluid funds (Compston 2009). Table 1 shows the resources held by the various AMH stakeholders.

\subsection{Stakeholder influence}

"Influence" is the use of the capacity to effect change in an organization's decisions, policies, or behavior (Berger and Reber 2006). In this work, it serves as a proxy for the perceived criticality of the resource/s held by a group of stakeholders. Resources include monetary, commercial, political, and technological support. Since critical resources are held by external stakeholders, those stakeholders with the ability to withhold resources can create leverage to influence others in the system.

\section{Stakeholders in a maritime network}

The maritime industry has evolved from an independent to a networked existence (Notteboom and Winkelmans 2003). Regulatory bodies are prominent for financial confidence, reliability of goods tracking, and cargo safety. One of the latest actors involved with maritime ventures is the environmental non-governmental group (NGO) that acts on behalf of the environment or an impacted population. Stakeholders involved in the venture increase the value of their resources by forming relations with each other to create a network. This network acts as a marketplace where resources are exchanged to create value.

Table 1 America's Marine Highway stakeholders and their resources

\begin{tabular}{|c|c|c|}
\hline & AMH stakeholder & Examples of types of support/resources \\
\hline (1) & Port operators & Cooperation with implementation, information, \\
\hline (2) & Vessel operators & $\begin{array}{l}\text { and time by avoiding delay causing } \\
\text { maneuvers such as recourse to courts } \\
\text { (American Waterways Operators (AWO) } \\
\text { 2019; IAPH, AAPA, ESPO, AIVP, \& PIANC, 2018). }\end{array}$ \\
\hline (3) & Shippers & Demand for ecofriendly services (Fries et al. 2010). \\
\hline (4) & Suppliers & $\begin{array}{l}\text { Cooperation with implementation in the form of } \\
\text { change in material supply e.g., low sulfur fuel, } \\
\text { low emission engines, and ecofriendly ship } \\
\text { design (Semolinos et al. 2013). }\end{array}$ \\
\hline (5) & Regulators & $\begin{array}{l}\text { Policy amendments and access to policymakers } \\
\text { (Kongsvik et al. 2014). }\end{array}$ \\
\hline (6) & Environmental NGOs & Information and political support (Peet 1994). \\
\hline (7) & Other modes & $\begin{array}{l}\text { Cooperation with implementation } \\
\text { (Van Der Horst and De Langen 2008). }\end{array}$ \\
\hline
\end{tabular}


This work presents a methodology for understanding stakeholder influence, applied within this niche market of US short sea shipping; it does not conduct a retrospective analysis of US maritime policy. The operations of this network are such that it shares the nature and proximity of its stakeholders more with domestic logistics than with international shipping. This work groups stakeholders into five general categories based upon their function; transportation providers (ports and vessel operators), customers (shippers and passengers), regulators, suppliers, and environmental advocates (Fig. 1). Stakeholders are grouped in a manner consistent with all transportation modes (modeneutral design) to permit cross-modal comparison, marine highways being part of the national transportation network.

\subsection{Transportation providers (terminal and vehicle operators)}

Transportation modes/providers are the main focus of this study. In the AMH context, they can be divided into two main groups that act as the primary service providers for the network: ports (terminals) and vessel (vehicle) operators.

The US Merchant Marine Act of 1920 (1920), Section 27 also known as Jones Act ("Jones Act," 1920, p. 999) states that "No merchandise ...shall be transported by water, or land and water, on penalty of forfeiture of the merchandise ..., between points in the United States, including Districts, Territories, and possessions thereof embraced within the coastwise laws, either directly or via foreign port, or for any part of the transportation, in any other vessel than a vessel built in and documented under the laws of the United States and owned by persons who are citizens of the United States..." The America's Marine Highways fall within the scope of the Jones Act and therefore have the same vessel ownership requirements.

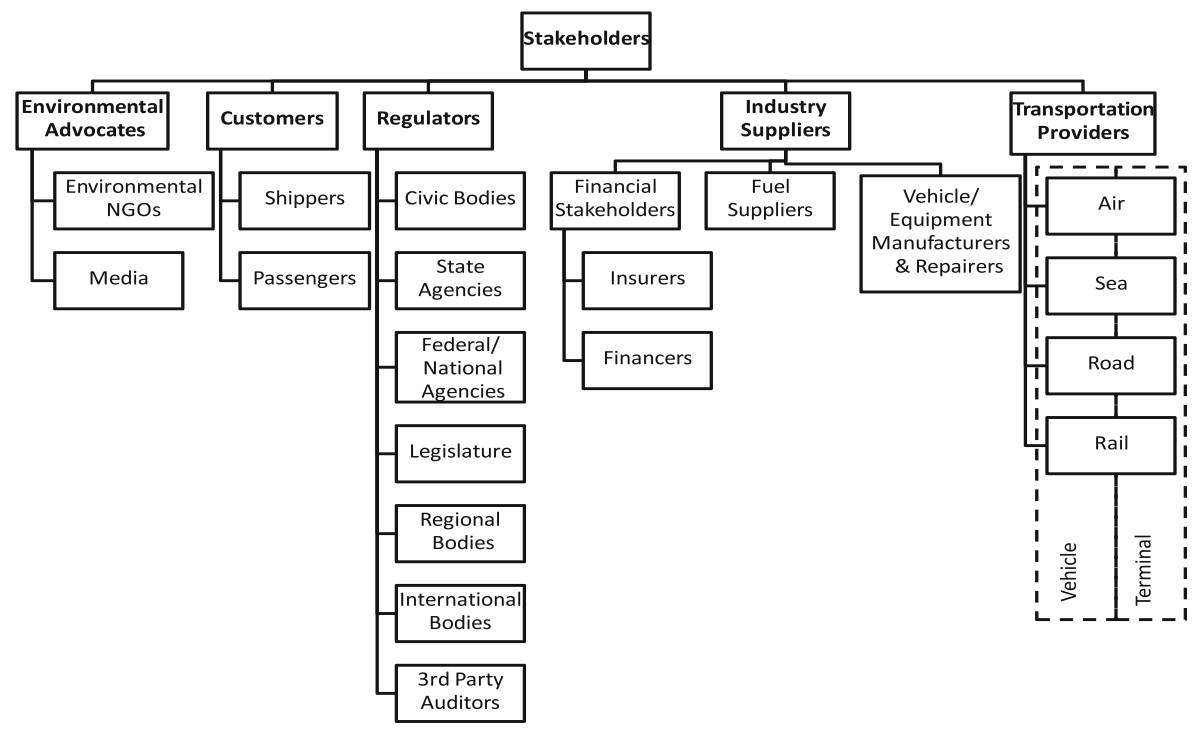

Fig. 1 America's Marine Highway stakeholders. The above figure shows the members of different marine highway stakeholder groups. This model is "mode-neutral." Therefore, the terms selected are the type that can be used for any mode, e.g., vehicle and terminal 
The demands placed of vessels suitable for AMH operations make them expensive to construct and operate (CSI 2005). The US Maritime Administration funded a design project that proposed 11 different designs deemed suitable for AMH operations (HEC 2011). The designs prepared included Roll-On/Roll-Off (RoRo), RoRo/Container Carrier (Rocon), container feeder ship, and a RoRo passenger ship (Ropax). The factors considered in the design process included type of cargo, market, routes, military capability, Jones Act, efficiency, subsidy, manning, environmental as well as other regulatory requirements.

AMH operators need other modes to provide the end-to-end, door-to-door, transportation service (Paixão and Marlow 2002). Ports are the interfaces between the transportation modes, i.e., they enable the use and interchange of modes (Bonsall 1998). Thus, seaports enable interchange between seaways and land-based modes such as road and rail. For a marine highway network (as opposed to ocean shipping), the role of ports and terminals is far more critical than the vessel speed as the efficient shift in mode (reduction in dwell time) contributes considerably to the time taken and thus the viability of the multimodal haul (Alderton 2008; Bagnell et al. 2009; Becker et al. 2004; Johnson and Styhre 2015; Paixão and Marlow 2002; Rodrigue et al. 2013). Since the AMH cannot function without the interphases, particularly in the multimodal environment, they are treated together as a singular entity, i.e., transportation providers.

\subsection{Customers (shippers/passengers)}

Transportation is a service industry, which functions in response to the demands of its customers. In the marine highways context as a modal alternative to road haul, these are the (breakbulk) shippers and (ferry) passengers. One of the critical developments in the customers' (shippers) attitudes has been the shift from the traditional operational approach of the economic order quantity (EOQ) focused on minimizing the costs of ordering and holding inventory (Min and Sui Pheng 2005), towards broader just-in-time philosophy, requiring smaller, more frequent shipments (UNCTAD 2018) dependent on reliable, and responsive transportation (Lai and Cheng 2009). This shift in attitude is both an opportunity as well as a threat to the ports and vessel operators. Traditionally, maritime transportation has not been the ideal candidate for a shipper seeking those attributes. However, changes in technology, as well as attitudes, may help. The new vessel designs proposed for the American Marine Highways while varied do tend to be generally smaller, faster, multipurpose (can carry smaller parcels of different types of cargoes) vessels with RoRo ramps (either dedicated RoRo or RoCon ships) (HEC 2011). Other related developments like automatic identification system (AIS), automated cargo/container handling, and information sharing are likely to improve the efficiency as well as reliability of the service provided by the AMH operators to each other (carriers and port operators), as well as their customers/shippers. Marine highways have varying degrees of direct benefit in terms of door-to-door freight costs for the shipper. However, they also provide many indirect benefits for both the shipper as well as the society in general.

\subsection{Regulators}

Marine highways, being part of the national transportation network, share similar regulatory oversight as the other modes with additional international requirements as 
lead down by the International Maritime Organization. Of significant relevance is the role of independent auditors such as the classification societies. While these entities do not possess direct authority, their expertise contributes to the legitimacy of their certificates/endorsements. These certificates are relied upon by other bodies to establish the seaworthiness of ships.

\subsection{Suppliers}

This category encompasses all the service providers that enable the maritime venture. Broadly, these include financiers, insurers, fuel suppliers, ship store/provisions suppliers, shipbuilders and repairers, and other equipment manufacturers and suppliers. Often suppliers undertake more than one role, e.g., shipbuilders and ship suppliers also provide financial support in the form of credit, which in turn can be the deciding factor for selection. There are also examples of shipbuilders and financers turning shipowners. Shipbuilders often during lean times build ships even when no order has been placed to keep the workforce occupied, thereby becoming de facto shipowners that even operate the vessels till a suitable buyer is identified. Financers also end up as de facto owners when they foreclose on a lien; this was one of the reasons for the development of the ship management industry. This group is necessarily diverse, by definition, although further investigations could disaggregate and evaluate the co-influence of suppliers in more detail.

\subsection{Environmental advocates}

Environmental advocates are special interest groups, environmentally active media, and NGOs that advocate protection of the environment and conservation of resources. This category of stakeholders that have gained salience by their role as environmental representatives of the grass-root public. Benefits of AMH from environmental perspective include improved energy efficiency, reduced air pollution, and reduced highway noise (Perakis and Denisis 2008).

Subsequent sections discuss the method used to collect quantitative data on influence as well as the results of the endeavor.

\section{Methods}

\subsection{Stakeholder network analysis}

Stakeholder networks can be analyzed by focusing on stakeholders (their attributes), their relations (resource dependence), or the outcome of their attributes and their relations in terms of the stakeholders' positions on issues. The form that the analysis might take depends on the reasons motivating the analysis. This work primarily explores stakeholder analysis as a tool for better environmental policy making (for business strategies and public policy). Legislators often need to be supported by "predigested, explicitly evaluative information which takes into account the political as well as the policy implication" (Kingdon 1973; Schneier and Gross 1993). Morgan and Peha (2003) have emphasized the importance of "making the stakeholder reactions 
part of the process..." so that policy makers "...not only learn what stakeholders prefer, they also learn the strength of those preferences."

In this work, influence diagrams are used to analyze and illustrate stakeholder relationships. To understand the dynamics of this network, stakeholder analysis uses "influence" as a proxy for the criticality of the resources held by a group of stakeholders. We use the links between the stakeholder groups to represent the strength (e.g., criticality) of dependence on resources. This resource dependence manifests itself in the form of influence that the possessor of the resource has on the demander. A comparative scale is used, as influence is an abstract attribute. Another option would be to develop an absolute scale using examples, but this approach was considered less reliable than a relative scale on both theoretical and practical bases. The magnitude and the direction of the influence are represented by the arrows. There is another very important source of influence: the members of the group itself, i.e., peers. These are, therefore, included as a category for consideration.

\subsection{Analytic hierarchy process}

Analytic hierarchy process (AHP), a multicriteria decision making method (MCDM) used for group decision making (GDM), aggregates the judgments of respondents assuming their homogeneity (Mardle et al. 2004; Solms 2009). This is difficult to achieve in a multistakeholder environment, particularly when respondents reflect diverse preferences. Thus, this study grouped similar stakeholder clusters (Fig. 1) and aggregated responses using the geometric mean of the judgments. This approach merges the individual respondent's identity, and uses the algebraic mean of individual priorities, thus maintaining the individual group's identity (Forman and Peniwati 1998). Harmonization of stakeholder judgments was not possible due to a remote and individual collection of responses and the small size of the population surveyed. Any attempts at harmonizing could also be counterproductive due to the possibility of "groupthink," i.e., irrational choice to conform to a consensus (Janis 1982; Solms 2009).

Comparion ${ }^{\circledR}$, a web-based tool, along with emails and phone for communication, facilitated the survey process. Because Comparion ${ }^{\circledR}$ has a seamless interface with Expert Choice ${ }^{\circledR}$ AHP software and can calculate AHP results independently to verify survey results, it was selected for collecting survey responses. A combination of Comparion ${ }^{\circledR}$ and Expert Choice ${ }^{\circledR}$ is used to identify stakeholder's influencers and their environmental preferences. Thomas L. Saaty developed AHP in the 1970s (Schmoldt 2001). It uses pairwise comparisons and calculates overall ratios using eigenvectors. Survey respondents access Comparion ${ }^{\circledR}$ using a link embedded in the invitation email. Its intuitive graphic interface provides a convenient mode of comparing two criteria.

\subsection{Survey}

This research surveyed AMH stakeholders from a variety of geographic locations in the USA in order to capture a wide range of representatives of the AMH. The survey targeted a nationwide audience, with an additional focus on the Great Lakes (part of America's Marine Highway) stakeholders (Fig. 1). Potential respondents in leadership 
positions were identified and selected through a search of entities involved in the AMH initiative (e.g., through Journal of Commerce, North American Marine Highways \& Logistics Conference Delegates, Greenwood's Guide to Great Lakes Shipping). The survey was thus non-probabilistic, purposive sampling of the total identified population. These respondents were asked to complete a pairwise comparison of influence exerted by the five main types of stakeholders (environmental advocates, shippers/ passengers, regulators, suppliers, and transportation) on their operations. They were asked about their perception of influence exerted on them and not exerted $b y$ them. This produces a ratio of influences acting on a group.

Respondents were further asked to evaluate the influence of their own group, as well to give an idea of peer influence/pressure. One hundred thirty-one valid responses were received from 617 survey invitations sent $(21.2 \%)$. The number of comparisons required in AHP is $N \times(N-1) / 2, N$ being the number of nodes in a cluster (Forman and Selly 2001). This means a rapid rise in the number of comparisons required with the increase in the number of criteria (stakeholder groups in this case). Therefore, while the respondents have only been asked to evaluate the five groups, the ability to sort the respondents into many more subgroups has been maintained as shown in Fig. 1.

Since the values derived are ratios, we cannot add them to calculate secondary influence. Furthermore, these are relative (not absolute) values. So, the 0.4 or $40 \%$ influence on group A by group B may be less than 0.3 or $30 \%$ on group C by group $\mathrm{D}$. The pooling of results within a stakeholder group is made using the geometric mean of their individual judgments, as the group is treated as a singular entity. The pooling of global priorities for the entire network is done using the arithmetic mean of stakeholder group priorities, which retains their individuality (Forman and Peniwati 1998).

In sum, this study and the survey that supported it had some unique features:

1. The same model is used for all respondents.

2. The respondents' group is not identified in the survey instrument.

3. The peers are not identified as a separate category in the survey instrument.

4. Since there is no explicit categorization done by the investigators before the invitation to participate in the survey or by respondents in the survey, the process mimics a double-blind study.

\section{Results and discussion}

The results of the survey are given in Table 2 .

Figure 2 graphically represents 25 stakeholder relationships within the marine highway network. The five main groups are denoted as circles, while the influence exerted on them is shown by the arrows heading in. The thickness of the circles shows the influence that the group exerts on its members, i.e., peer influence/ pressure. The size of the circle shows the aggregate influence the group exerts on the network. The thickness of the lines shows the comparative influence exerted while their shade or pattern the consensus or lack thereof (variation) in terms of standard deviation in the responses. 
Table 2 Stakeholder influence survey results

\begin{tabular}{|c|c|c|c|c|c|c|c|}
\hline & \multicolumn{5}{|c|}{ Influencers } & \multirow{2}{*}{ 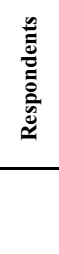 } & \multirow{2}{*}{ 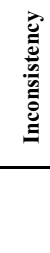 } \\
\hline & $\begin{array}{c}\text { Environmental } \\
\text { Advocates }\end{array}$ & $\begin{array}{c}\text { Shippers/ } \\
\text { Passengers }\end{array}$ & $\begin{array}{c}\text { Transportation } \\
\text { Providers }\end{array}$ & Suppliers & Regulators & & \\
\hline \multirow{2}{*}{ Groups } & Influence & Influence & Influence & Influence & Influence & & \\
\hline & $\begin{array}{l}\text { Consensus } \\
\text { (Std. Dev.) }\end{array}$ & $\begin{array}{l}\text { Consensus } \\
\text { (Std. Dev.) }\end{array}$ & $\begin{array}{l}\text { Consensus } \\
\text { (Std. Dev.) }\end{array}$ & $\begin{array}{l}\text { Consensus } \\
\text { (Std. Dev.) }\end{array}$ & $\begin{array}{l}\text { Consensus } \\
\text { (Std. Dev.) }\end{array}$ & & \\
\hline \multirow{2}{*}{$\begin{array}{c}\text { Environmental } \\
\text { Advocates }\end{array}$} & 0.3361 & 0.1737 & 0.1314 & 0.0849 & 0.2739 & \multirow{2}{*}{9} & \multirow{2}{*}{0.02} \\
\hline & $21.17 \%$ & $12.86 \%$ & $13.57 \%$ & $03.20 \%$ & $07.49 \%$ & & \\
\hline \multirow{2}{*}{$\begin{array}{c}\text { Shippers/ } \\
\text { Passengers }\end{array}$} & 0.0651 & 0.2723 & 0.2393 & 0.1695 & 0.2539 & \multirow{2}{*}{6} & \multirow{2}{*}{0.04} \\
\hline & $03.95 \%$ & $13.60 \%$ & $05.67 \%$ & $09.08 \%$ & $13.64 \%$ & & \\
\hline \multirow{2}{*}{$\begin{array}{c}\text { Transportation } \\
\text { Providers }\end{array}$} & 0.1081 & 0.2948 & 0.2810 & 0.0632 & 0.2529 & \multirow{2}{*}{49} & \multirow{2}{*}{0} \\
\hline & $07.44 \%$ & $16.36 \%$ & $17.49 \%$ & $04.36 \%$ & $17.36 \%$ & & \\
\hline \multirow{2}{*}{ Suppliers } & 0.0785 & 0.2466 & 0.2912 & 0.1296 & 0.2539 & \multirow{2}{*}{31} & \multirow{2}{*}{0.02} \\
\hline & $06.73 \%$ & $13.55 \%$ & $16.78 \%$ & $14.91 \%$ & $17.42 \%$ & & \\
\hline \multirow{2}{*}{ Regulators } & 0.1787 & 0.1526 & 0.2000 & 0.0941 & 0.3746 & \multirow{2}{*}{36} & \multirow{2}{*}{0.01} \\
\hline & $13.41 \%$ & $11.86 \%$ & $11.64 \%$ & $07.51 \%$ & $18.61 \%$ & & \\
\hline $\begin{array}{c}\text { Algebraic } \\
\text { Mean (AIP) }\end{array}$ & 0.1533 & 0.2280 & 0.2286 & 0.1083 & 0.2818 & 131 & \\
\hline
\end{tabular}

Group survey results are in rows and influencers are in columns. Each influence score has the corresponding consensus below it and the pooled group inconsistency in the last column. The highest influence scores (denoting most dominant influencers) for each group are in italics. The network-wide results are given using the algebraic mean of the group scores in the bottom row. Standard deviations from 0 to $10 \%$ are in green, $10-$ $20 \%$ are in purple and above $20 \%$ are in red (high to low, degree of consensus among respondents). Low standard deviation suggests greater consensus among respondents

There are essentially three types of influence values that emerged in this analysis: intragroup (peer influence), intergroup (dyadic), and network. The pooling of results within a stakeholder group, which provides the intragroup and intergroup influences, uses the geometric mean of the individual group member's judgments. The pooling of group priorities for the entire network is done using the arithmetic mean of stakeholder group priorities. Figure 2 illustrates these relationships in the marine highway stakeholder network. This section analyzes the results to understand the causes behind them.

\subsection{Intragroup relations: the influence of peers on their groups}

These are relations among members of a group. We see their interdependence in the form of peer influence or the influence of their peers. Table 2 shows how peers are the greatest influencers in all stakeholder groups except suppliers and transportation providers. The dominance of peer influence is consistent with observations made in sales (Sikand 2011). In a seller-buyer relation within a buyer-dominated market, it is logical to expect the buyer to have a strong influence on the seller. This is witnessed in 


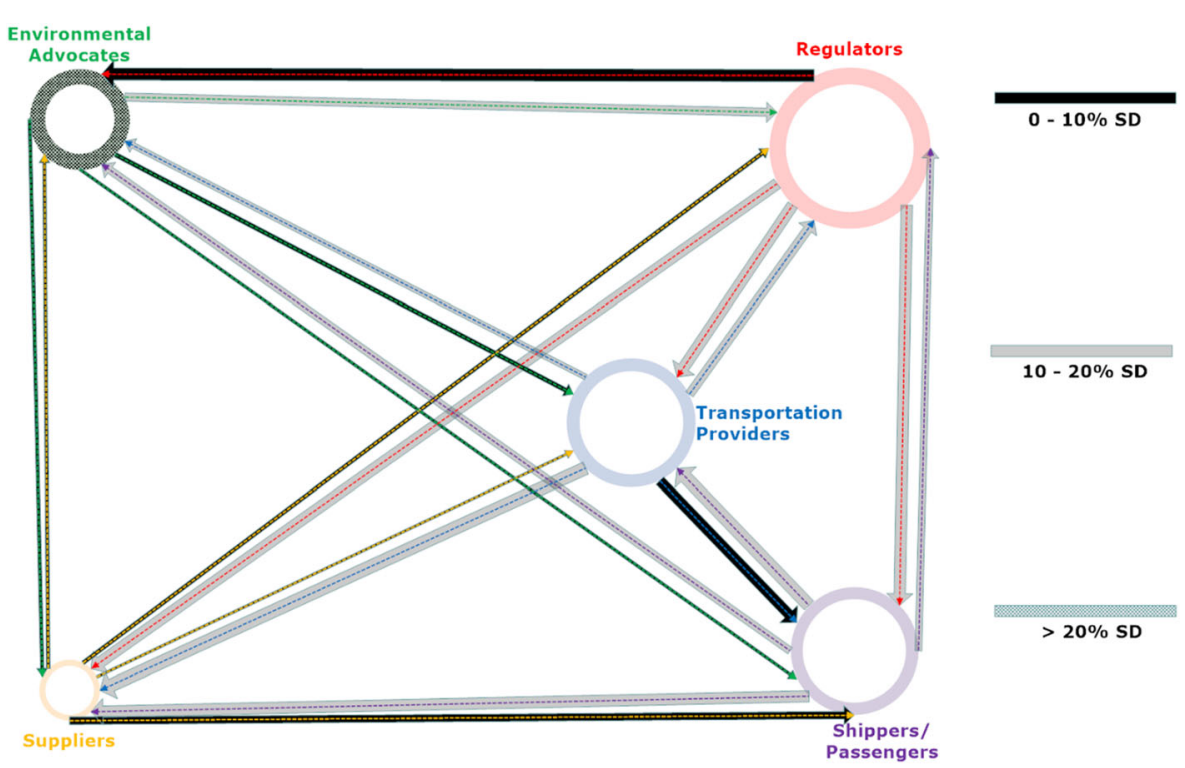

Fig. 2 America's Marine Highway stakeholder influence network (to scale). This figure graphically represents the results of the stakeholder survey given in Table 2. Circles denote the stakeholder groups. Their diameters show the relative aggregate influence of the group within the network. Circle thickness shows their relative peer influence (influence of group members on each other). The thickness and direction of the arrows show the relative magnitude and direction of influence between groups. The shading/pattern of the lines shows the consensus of the respondents around the value. The position of the circles in the figure has no implied significance

the supplier and transportation provider groups, where the corresponding buyer groups have the strongest influence. Transportation providers are customers (buyers) of the suppliers, while in turn being the sellers of transportation services to the shippers. Interestingly, transportation providers do seem to also have considerable group identity (peers 0.2871), which is close to the maximum influence exerted on the group, that is by their customers (shippers/passengers 0.2948). Strong peer influence helps them cooperate (not just compete) with each other to lobby for favorable policy changes. This relation contrasts with that of the suppliers who have very little peer influence (0.1296), which can be problematic when it comes to adopting innovative products such as alternative fuels.

\subsection{Intergroup (dyadic) relations: the influence of groups on each other}

Intergroup (dyadic) relations are relations between pairs of stakeholder groups. Influence values derived from the pairwise comparisons made by stakeholder respondents show the relative value of the stakeholder resources as perceived by the respondent group. These values were calculated using a geometric mean (aggregate) of individual judgments by respondents within a group, i.e., aggregating individual judgments (AIJs) (Forman and Peniwati 1998). Intergroup influence is probably most interesting from a network perspective. It is this influence that the stakeholders within the network will try to leverage. Mapping intergroup influences show the path of maximum power between 
and over stakeholder groups. An excellent example of these relations is that of between environmental advocates and transportation providers. Transportation operations, particularly those of ships, have a considerable ecological impact. Environmental advocates have often tried to induce ship operators to improve their environmental performance. They (environmental advocates), however, have limited direct influence on the ship operators (0.1081). Environmental advocates, however, do have considerable influence on the regulators (0.1787), who, in turn, have maximum influence on the ship operators (0.2529). Environmental advocates are, therefore, able to effectively influence the ship operators by working with the regulators. Here, the resources traded by the environmental advocates are the goodwill/endorsement of the environmentconscious public with the regulators (Mitchell et al. 1991), in exchange for favorable policy for the ship operators, to induce improved environmental performance (MARAD and EPA 2011).

\subsection{Network relations-aggregate group (network) influence on each group}

The group influence number represents the aggregate value of the stakeholder group's resource within the network, i.e., quantifies the overall influence of a group within the network. Since the number is derived from the responses of five distinctly different groups, algebraic mean (aggregate) of the group priorities has been used to maintain the individual group identity that is "aggregating individual priorities (AIPs)" (Forman and Peniwati 1998). As these values refer to aggregate group influences, each group is considered as an equal singular entity with all constituent members having equal intragroup influence. The overall dominance of the regulators is obvious in these results (0.2818), along with the lack of same by the environmental advocates (0.1533). These results could be a reflection of the culture prevailing in the marine industry in the USA. It is reasonable to assume that a similar inland and short sea shipping network in Europe would have significantly different influence values for these groups.

\subsection{Comparisons of intragroup and intergroup influences}

This study demonstrates the strength of peer influence within the various AMH stakeholder groups. In three out of five groups of stakeholders (shippers/passengers, environmental advocates, and regulators), respondents reported that their peers influenced their operational decisions the most. Both transportation providers and suppliers have a competitive business environment that justifies lower peer and higher customer influence. Overall, regulators have the highest influence in the network (0.2818). This suggests that a regulators' lead initiative has the best hope of success. As depicted in Fig. 2, the low influence exerted by the environmental advocates on the shippers suggests that these groups have little power to induce better environmental performance from transportation providers (maritime operators). On the other hand, environmental advocates have a relatively strong relationship with the regulators, who in turn are among the strongest external influencers of the transportation providers. Thus, while environmental groups may not be in a position to directly influence a given firm, they do play a strong role in shaping policy. 


\subsection{Heterogeneity of groups}

Operators of AMH vessels are a dynamic and heterogeneous group, i.e., their choices/ costs vary between each other as well as possibly over time. In the context of the implementation of a policy for marine highways, the high peer influence exhibited in 3 out of 5 groups could overcome the divergence in opinion (groupthink). Respondents that provide distinctly varied services to the marine highway operators (MHOs) were grouped under the category "suppliers." Functionally, this is true, i.e., their role is that of suppliers. However, their relations with the marine highway stakeholders as well as with others grouped in the supplier category varies. Combining these varied service providers under the generalized designation as suppliers were necessitated by the need to contain the model and the required responses to a reasonable size. AHP analysis requires pairwise comparisons between criteria. The number of comparisons required in AHP is $N \times(N-1) / 2, N$ being the number of nodes in a cluster (Forman and Selly 2001). Therefore, adding a separate group or splitting a group considerably increases the responses required, which, in turn, reduces the response rate of complete responses. The results obtained from the survey could have several possible interpretations. One that makes sense in the maritime context is that the suppliers, in general, listen to their customers more than their peers. Future work could explore these service providers as separate entities for a better understanding of the relations between them and between them and other stakeholder groups.

\section{Limitations}

This research has been an exercise in group decision making. Some unique challenges were faced in this process. One limitation of the survey was the low/asymmetric response rate among groups. The need to solicit and incorporate stakeholder priorities from representatives in leadership positions, who are often too busy to respond to surveys, reduced the response rate. Of some concern is the limited number of shippers that have responded (6). The reason for this was the commercial sensitivity of the information, i.e., the identity of the shippers. These small numbers do not have a methodological impact, as AHP is often used for small groups or even individuals. It should also be noted that since we are working with geometric means (AIJ) for intergroup and intragroup influences and algebraic means (AIP) for network influences, we are comparing means to means. Therefore, the varying number of respondents within each group does not skew the results. However, the reliability/(statistical) significance of the results does suffer from fewer responses. Therefore, a larger sample is recommended before fully interpreting these results.

\section{Conclusion}

This study explored the influence held by five AMH system stakeholder groups in the broad contexts of policy and management. Results describe how five groups (environmental advocates, shippers/passengers, transportation providers, suppliers, regulators) perceive the influence of their peers, the other groups, and the network as a whole in 
their decision making. Making a positive change in a system as complex and diverse as the America's Marine Highway system is particularly challenging due to varied incentive structures, mandates, and priorities of the individual actors. Thus, if an entity, such as an environmental advocate, wishes to initiate changes, it must seek appropriate entry points in the decision system and understand the influence pathways. For example, actions such as switching to more environmentally friendly vessel fuel sources or changing shipping routes to avoid whale migration areas could find willing vessel operators if regulators advocated such actions. This work benefits the stakeholders of the AMH, as it illustrates how the decision system operates with respect to groups' influence on each other and their peer networks. Each group within the system can understand how to elicit cooperation from other groups by targeting those in the system which hold the greatest influence. Notably, regulators hold the highest level of influence over all groups. Environmental advocates can influence regulators but have less of an influence on the marine highway operators that make up the AMH system. Thus, they may benefit from reaching out to regulators, who would in turn act as proxies to help advocates achieve the desired environmental performance from the marine highway operators. Finally, this work endeavored to not just find the influences between the stakeholder groups but also communicate them for policymakers. The latter was efficiently done visually using a novel method developed by the authors. Its utility can be confirmed by comparing the ability to assimilate the results from Table 2 using the numerical values given, with the graphical depiction of the same in Fig. 2.

Acknowledgments Authors would like to thank the AMH stakeholder survey respondents for their time and patience in responding to the survey questionnaire.

Funding information This study was partly funded by the Maritime Administration an agency within the U.S. Department of Transportation.

Open Access This article is licensed under a Creative Commons Attribution 4.0 International License, which permits use, sharing, adaptation, distribution and reproduction in any medium or format, as long as you give appropriate credit to the original author(s) and the source, provide a link to the Creative Commons licence, and indicate if changes were made. The images or other third party material in this article are included in the article's Creative Commons licence, unless indicated otherwise in a credit line to the material. If material is not included in the article's Creative Commons licence and your intended use is not permitted by statutory regulation or exceeds the permitted use, you will need to obtain permission directly from the copyright holder. To view a copy of this licence, visit http://creativecommons.org/licenses/by/4.0/.

\section{References}

Alderton PM (2008) Port management and operations, 3rd edn. Informa, London

American Waterways Operators (AWO) (2019) Press Kit [Press release]. Retrieved from https://www. americanwaterways.com/sites/default/files/2019PressKit.pdf. Accessed 2 Apr 2020

Bagnell D, Saunders C, Silva R, Tedesco MP (2009) Operational development of marine highways to serve the U.S. Pacific coast. Transp Res Rec 2100(1):76-85. https://doi.org/10.3141/2100-09

Becker JFF, Burgess A, Henstra DAJME, Logistics (2004) No need for speed in short sea shipping. 6(3):236251. https://doi.org/10.1057/palgrave.mel.9100111

Berger BK, Reber BH (2006) Gaining influence in public relations: the role of resistance in practice. Lawrence Erlbaum Publishers, Mahwah 
Bonsall S (1998, 10/1998). [ENGMRM012 maritime transport systems]

Clarkson MBE (1994) A risk based model of stakeholder theory Paper presented at the Proceedings of the Second Toronto Conference on Stakeholder Theory Toronto

Compston H (2009) Policy networks and policy change: putting policy network theory to the test. Palgrave Macmillan, Basingstoke

CSI (2005) Short-sea and coastal shipping options study Retrieved from http://temis.documentation. developpement-durable.gouv.fr/docs/Temis/0060/Temis-0060304/16566.pdf. Accessed 2 Dec 2018

Forman E, Peniwati K (1998) Aggregating individual judgments and priorities with the analytic hierarchy process. Eur J Oper Res 108(1):165-169 Retrieved from http://www.sciencedirect.com/science/article/B6 VCT-3TC6THR-19/2/379c4b553d9827927aa26aa55f987e80. Accessed 7 Oct 2012

Forman EH, Selly MA (2001) Decision by objectives: how to convince others that you are right. World Scientific, River Edge

Freeman RE (ed) (2010) Stakeholder theory : the state of the art. Cambridge University Press, Cambridge

Friedman AL, Miles S (2006) Stakeholders: Theory \& Practice. Oxford University Press, Oxford

Friedman M (2007) The social responsibility of business is to increase its profits. in: Zimmerli WC, Holzinger M, Richter K (eds) Corporate ethics and corporate governance. Springer Berlin Heidelberg, Berlin, Heidelberg, pp 173-178. https://doi.org/10.1007/978-3-540-70818-6_14

Fries N, de Jong GC, Patterson Z, Weidmann U (2010) Shipper willingness to pay to increase environmental performance in freight transportation. Transp Res Rec 2168(1):33-42. https://doi.org/10.3141/2168-05

HEC (2011) American Marine Highway Design Project (MARAD DTMA1C10061). 1200 New Jersey Avenue, SE, Washington, DC 20590. Retrieved from https://www.marad.dot.gov/wpcontent/uploads/pdf/AMH_Report_Final_Report_10282011_updated.pdf. Accessed 12 Nov 2018

IAPH, AAPA, ESPO, AIVP, PIANC (2018) World Ports Sustainability Program (WPSP) Charter. International Association of Ports and Harbors (IAPH), European Sea Ports Organisation (ESPO), International Association of Cities and Ports (AIVP), World Association for Waterborne Transport Infrastructure (PIANC). https://sustainableworldports.org. Accessed 14 March 2018

Janis IL (1982) Groupthink : psychological studies of policy decisions and fiascoes, 2nd edn. Houghton Mifflin, Boston

Johnson H, Styhre L (2015) Increased energy efficiency in short sea shipping through decreased time in port. Transp Res A Policy Pract 71:167-178. https://doi.org/10.1016/j.tra.2014.11.008

Kingdon JW (1973) Congressmen's voting decisions. Harper \& Row, New York

Klijn E-H (2008) The Oxford handbook of inter-organizational relations. In: Cropper S, Ebers M, Huxham C, Smith Ring P (eds) Oxford handbooks. Oxford University Press, Oxford, pp 118-146

Knoke D, Chen X (2008) Political Perspectives on Inter-Organizational Networks. In: Cropper S (ed) The Oxford handbook of inter-organizational relations. Oxford University Press, Oxford, p xxiv, $782 \mathrm{p}$

Kongsvik TØ, Størkersen K, Antonsen S (2014) The relationship between regulation, safety management systems and safety culture in the maritime industry. Safety, Reliability and Risk Analysis: Beyond the Horizon, 467-473

Lai K-h, Cheng TCE (2009) Just-in-time logistics. In: Farnham, England. Gower, Burlington

MARAD, EPA (2011) America's Marine Highway Report to Congress

Mardle S, Pascoe S, Herrero I (2004) Management objective importance in fisheries: an evaluation using the analytic hierarchy process (AHP). Environ Manag 33(1):1-11. https://doi.org/10.1007/s00267-003-3070$\mathrm{y}$

Merchant Marine Act of 1920 (1920) § Twenty-Seven 988-1008 (1920 06/05/1920)

Min W, Sui Pheng L (2005) Economic order quantity (EOQ) versus just-in-time (JIT) purchasing: an alternative analysis in the ready-mixed concrete industry. Constr Manag Econ 23(4):409-422. https://doi.org/10.1080/01446190500041339

Mitchell RC, Mertig AG, Dunlap RE (1991) Twenty years of environmental mobilization: Trends among national environmental organizations. Soc Natural Resour 4:219-234. https://doi.org/10.1080 $/ 08941929109380756$

Molm LD (2010) The structure of reciprocity. Soc Psychol Q 73(2):119-131 Retrieved from http://www.jstor. org/stable/25677393. Accessed 29 Jul 2018

Morgan MG, Peha J (Eds.) (2003) Science and Technology Advice for Congress Washington: Resources for the Future

Musso E, Casaca ACP, Lynce AR (2010) Economics of Short Sea shipping. In: Grammenos CT (ed) The handbook of maritime economics and business. Lloyd's List, London, pp 391-430

National Research Council (U.S.). Committee for a Study of the Federal Role in the Marine Transportation System (2004) The marine transportation system and the Federal Role: measuring performance, targeting improvement. Transportation Research Board, Washington 
Notteboom T, Winkelmans W (2003) Dealing with stakeholders in the port planning process. In Across the border: building upon a quarter century of transport research in the Benelux.-Antwerpen, 2003 (pp. 249265)

Paixão AC, Marlow PB (2002) Strengths and weaknesses of short sea shipping. Mar Policy 26(3):167-178. https://doi.org/10.1016/S0308-597X(01)00047-1

Peet G (1994) The role of (environmental) non-governmental organizations at the Marine Environment Protection Committee (MEPC) of the International Maritime Organization (IMO), and at the London Dumping Convention (LDC). Ocean Coast Manag 22(1):3-18. https://doi.org/10.1016/0964-5691(94 )90080-9

Perakis AN, Denisis A (2008) A survey of short sea shipping and its prospects in the USA. Marit Policy Manag 35(6):591-614. https://doi.org/10.1080/03088830802469501

Rodrigue J-P, Comtois C, Slack B (2013) The geography of transport systems, 3rd edn. Routledge, London

Roome N (2001) Conceptualizing and studying the contribution of networks in environmental management and sustainable development. Bus Strateg Environ 10(2):69-76. https://doi.org/10.1002/bse.276

Rowley TJ (1997) Moving beyond dyadic ties: a network theory of stakeholder influences. Acad Manag Rev 22(4):887-910 Retrieved from http://www.jstor.org/stable/259248. Accessed 7 Oct 2012

Schmoldt DL (2001) The analytic hierarchy process in natural resource and environmental decision making. In: Dordrecht. Kluwer Academic Publishers

Schneier EV, Gross B (1993) Legislative strategy: shaping public policy. St. Martin's Press, New York

Semolinos P, Olsen G, Giacosa A (2013) LNG as marine fuel: challenges to be overcome. Paper presented at the 17th International Conference \& Exhibition on liquefied natural gas, TOTAL Gas \& Power, Houston

Sikand A (2011). Peer influence vs. manager authority—which wins? Sales Practice. The Sales Challenger ${ }^{\mathrm{TM}}$. News and Insight from the Team. Retrieved from http://saleschallenger.exbdblogs.com/2011/08/23/peerinfluence-vs-manager-authority\%e2\%80\%94which-wins/. Accessed 16 Nov 2011

Smith A (2007) An inquiry into the nature and causes of the wealth of nations. In: Soares SM (ed) Books I, II, III, IV and V. MetaLibri digital library, p 754

Solms SV (2009) Homogeneity and choice aggregation in the analytic hierarchy process. Paper presented at the ISHAP 2009 IProceedings of the international symposium on the analytic hierarchy process for multicriteria decision making, Pittsburgh. http://www.isahp.org/2009Proceedings/Final_Papers/93_von_ Solms Homogeneity and Choice Aggregation REV FIN.pdf. Accessed 7 Oct 2012

UNCTAD (2018) 50 years of review of maritime transport, 1968-2018: reflecting on the past, exploring the future. Retrieved from https:/unctad.org/en/PublicationsLibrary/dtl2018d1_en.pdf. Accessed 2 Apr 2019

Van Der Horst MR, De Langen PW (2008) Coordination in hinterland transport chains: a major challenge for the seaport community. Marit Econ Logist 10(1):108-129. https://doi.org/10.1057/palgrave.mel.9100194

World Ports Sustainability Program (WPSP) Charter (2018)

Publisher's note Springer Nature remains neutral with regard to jurisdictional claims in published maps and institutional affiliations. 